Review Article

\title{
Studies on diversity and evolution of Iridaceae species in southern Brazil
}

\author{
Tatiana T. Souza-Chies ${ }^{1,2}$, Eliane Kaltchuk dos Santos ${ }^{1,3}$, Lilian Eggers ${ }^{2}$, Alice Mainieri Flores ${ }^{2}$, \\ Eudes M. Stiehl Alves ${ }^{1}$, Juliana Fachinetto ${ }^{1}$, Juliana Lustosa ${ }^{1}$, Lauís Brisolara Corrêa ${ }^{1}$, \\ Luana Olinda Tacuatiá ${ }^{1}$, Paula Piccoli ${ }^{3}$ and Rogéria Beatriz Miz ${ }^{1}$ \\ ${ }^{1}$ Programa de Pós-Graduação em Genética e Biologia Molecular, \\ Universidade Federal do Rio Grande do Sul, Porto Alegre, RS, Brazil. \\ ${ }^{2}$ Departamento de Botânica, Universidade Federal do Rio Grande do Sul, Porto Alegre, RS, Brazil. \\ ${ }^{3}$ Departamento de Genética, Universidade Federal do Rio Grande do Sul, Porto Alegre, RS, Brazil.
}

\begin{abstract}
Plants of the family Iridaceae are well represented in the grassland vegetation of southern Brazil, occurring in the Pampa and Atlantic Forest biomes. Nevertheless, little is known about the taxonomy and evolution of Iridaceae species in southern Brazil. The main goal of this review is to compile published information about South American Iridaceae, and to discuss the evolution and genetic diversity of the family presenting our own research data in the light of the published literature. The main focus is on the genera Calydorea, Cypella, Herbertia, and Sisyrinchium. Aspects of reproductive system and of pollinator attraction are also discussed.

Keywords: cytotaxonomy, molecular phylogenetics, Iridoideae, population genetics, diversity.
\end{abstract}

\section{Iridaceae}

Iridaceae (Asparagales, Monocots) encompasses approximately 2,000 species distributed among 65 to 75 genera (Goldblatt et al., 2008). Among these species, approximately 160 occur in Brazil, representing 18 genera, and 12 of these genera are found in southern Brazil (Eggers et al., 2010). In terms of diversification and abundance, the most important Iridaceae genera in Brazil are Sisyrinchium L. (58 species), Neomarica Sprague, Pseudotrimezia R.C. Foster (21 species both), Trimezia Salisb. ex Herb. and Cypella Herb. (14 species both).

Iridaceae is one of the largest families of Monocots. It comprises plants with wide diversity of flowers and can be recognized by their petaloid perianth, or corolla, with three tepals of the inner whorl and the three of the outer whorl usually alike in texture, shape and often in color (but not in Sisyrinchium). Iridaceae is distinguished of other Asparagalean families by the three stamens in the androecium (Goldblatt and Manning, 2008). The family is quite interesting by multiple strategies and intimate associations with pollinating insects or birds due to the diversity of the flowers. Furthermore, some genera of Iridaceae are focus of research concerning the evolution of oil-producing struc-

Send correspondence to Tatiana T. Souza-Chies. Departamento de Botânica, Universidade Federal do Rio Grande do Sul, Av. Bento Gonçalves 9500, 91501-970 Porto Alegre, RS, Brazil. E-mail: tatiana.chies@ufrgs.br. tures related to specialized oil-bee pollination (Chauveau et al., 2011).

The tribes Tigrideae, Sisyrinchieae and Trimezieae from the subfamily Iridoideae have representatives in southern Brazil. Notwithstanding, species richness in Trimezieae is poor for this southern region, contrasting with the high diversity in southeastern Brazil. Important genera found in southern Brazil include Calydorea (nine species), Cypella (11 species) and Herbertia (six species) which belong to tribe Tigrideae and Sisyrinchium (45 species, tribe Sisyrinchieae) (Eggers et al., 2010). Tigrideae are characterized by the presence of bulbs and plicate leaves, whereas the Sisyrinchieae have rhizome or fibrous root system and plane or terete leaves. Also, very particular of Sisyrinchium are the partially or entirely united filaments (Goldblatt et al., 2008).

According to Rodriguez and Sytsma (2006), the clade Tigridieae groups several genera with very similar vegetative characteristics, making the differentiation of Tigridieae genera impracticable except during the flowering period. Also, broad morphological variability in the flowers is found within species, which is a source of confusion for the circumscription of many species. New World species of Iridaceae are found in Trimezieae, Tigridieae and Sisyrinchieae, the latter a well-supported clade that includes six genera (Libertia Spreng., Orthrosanthus Sweet, Olsynium Raf., Sisyrinchium, Solenomelus Miers, and 
Tapeinia Comm. ex Juss.) (Goldblatt et al., 2008). Among these genera, Sisyrinchium is the most diverse.

Sisyrinchium flowers have filaments that are partly connected or completely fused in a staminal column that may bear trichomes of different types. Elaiophores of various densities and extensions may be present in the staminal column, usually at its base, and function to attract specialized pollinator bees that use the oil produced by these trichomes to feed their larvae (Chauveau et al., 2011).

Iridaceae species exhibit a broad variety of flower colors and shapes that may serve as signal to pollinators (Goldblatt and Manning, 2008). Three major types of pollinator rewards are known. For example, the non-volatile oils produced in the elaiophores of many species (particularly in Sisyrinchium) attract specialized oil-collecting bees belonging to two Hymenoptera families, Mellitidae and Apidae (Michener, 2007). In an analysis of the evolutionary aspects of oil-bee pollination in almost 200 species, Renner and Schaefer (2010) showed that oil-bee pollination has evolved independently at least 28 times in different angiosperm families. A recent investigation of the evolution of oil-producing structures related to specialized oilbee pollination in Sisyrinchium and the phylogeny of the genus indicated that glandular trichomes have evolved independently three times (Chauveau et al., 2011). The occurrence of this type of plant-pollinator interaction in flowers providing oil as a reward is found in only 11 angiosperm families (Renner and Schaefer, 2010).

Great morphological variation can be observed in certain groups of Sisyrinchium species. S. micranthum Cav. is the most variable species, with morphotypes that can be characterized by a combination of different plant size and habit, flower size and color, and tepal organization. This variation has been discussed elsewhere (Chukr and Capellari $\mathrm{Jr}, 2003)$ and is not directly associated with ploidy levels (Tacuatiá et al., 2012b). When Chauveau et al. (2011) examined nine accessions of $S$. micranthum related to different morphotypes, they were unable to separate the taxa even though the phylogenetic tree displayed groups within the species.

Other taxa with morphological variation and taxonomic problems are related to Sisyrinchium palmifolium L. and $S$. vaginatum Spreng. Each of these species have many synonyms, representing species considered difficult to distinguish from the main cited ones (Johnston, 1938; Chukr and Capellari Jr, 2003). Notwithstanding, our preliminary investigations suggest that many of these synonyms must be again evaluated and that studies on a better characterization of these species are needed.

Besides the three taxa cited above, other Sisyrinchium species from southern Brazil are focused by our research group. These species are primarily members of the sections Scirpeocharis, Sisyrinchium, and Lenitium (sensu Ravenna). Examples of such species are S. luzula Klotzsch ex Klatt, S. pachyrhizum Baker, and S. sellowianum Klatt, respectively.

All taxa mentioned previously and which are under investigation by our research group do not have detailed information about the diversity and evolution of the species. We now address such questions in this review, keeping in focus this taxonomic group as a whole.

\section{Cytogenetic Data for Iridaceae}

Cytological data are now available for approximately $65 \%$ of Iridaceae species, primarily for those from the Old World taxa (Goldblatt and Takei, 1997; Alves et al., 2011). Although most of these data are limited to chromosome counts, the data available from cytogenetic studies suggest an interesting scenario for chromosome evolution. The great variation in aspects of Iridaceae karyology, such as karyotypic architecture, basic (monoploid) number $(x)$, and ploidy level, makes cytological analyses important for clarifying the systematics and evolution of this family (Goldblatt and Takei, 1997).

The basic chromosome number for Iridaceae remains uncertain, although ancestral chromosome numbers have been suggested for almost all genera (Goldblatt, 1990; Goldblatt and Takei, 1997). The most likely basic number is 10 , with many derived numbers such as $9,8,7$, and 5 . Goldblatt and Takei (1997) suggested that much of the variation in chromosome number results from descending disploidy. Heteromorphisms of the chromosome arms in some species also indicate the occurrence of unequal reciprocal translocations.

Chromosome numbers $(2 n)$ in the Iridaceae vary from 6 to approximately 230 , suggesting that polyploidy has been important in the evolution of Iridaceae species (Alves et al., 2011). Such variability is probably related to cycles of polyploidy and downward disploidy. Neopolyploidy is also common in the family, since intrageneric and intraspecific polyploidy are common, especially in the Northern Hemisphere.

Chromosome morphology and size vary greatly among Iridaceae species. Karyotype bimodality and asymmetry are frequent in the family, particularly in Iridoideae. Phylogenetic data indicate that bimodality has arisen several times in different lineages (Goldblatt et al., 2008). Although the Neotropics are considered the second most important center of diversity in Iridaceae (Goldblatt and Manning, 2008), studies of Neotropical Iridaceae have been few in number; cytogenetic studies have focused primarily on North American species, and karyological data from Brazilian species are scarce. Recently, Alves et al. (2011) reported chromosomal characterizations of 15 species of Iridaceae from northeastern Brazil, increasing to 24 the number of species in that region with cytological data.

There are few data for most of the Brazilian taxa, even for chromosome numbers counts, and for some of them, the only cytological data available are from species collected in 
other South American countries (Goldblatt and Takei, 1997; De Tullio et al., 2008; Moreno et al., 2009). Chromosome numbers were determined for the Calydorea species C. amabilis (Ravenna) Goldblatt \& Henrich, C. azurea Klatt, C. nuda Baker, C. pallens Griseb., and C. xiphioides (Poepp.) Espinosa, all of them with $x=7$, although three different diploid chromosome numbers were also found $(2 n=14,28$, or 42) (Goldblatt, 1982; Goldblatt and Takei, 1997). In a more recently published cytological report for Calydorea (De Tullio et al., 2008), the karyotype of Argentinean material of $C$. undulata Ravenna $(2 n=14)$ was described as bimodal, with two pairs of large chromosomes and five pairs of small chromosomes. Asymmetry was moderate, with meta- and submetacentric chromosomes, two of them satellited. Our preliminary cytological analyses for Calydorea alba Roitman \& A. Castillo, C. approximata R.C. Foster, C. campestris (Klatt) Baker, and $C$. crocoides Ravenna confirm the monoploid number $x=7$. Previous counts are not available for these species.

Chromosome numbers were described for seven species of Cypella (Ravenna, 1981; Goldblatt, 1982; Kenton et al., 1990; Goldblatt and Takei, 1997); for all but one, $2 n=$ 14 and $x=7$. Interestingly, C. coelestis (Lehm.) Diels, for which $2 n=10$, has a different generic position by some authors [as Phalocallis coelestis (Lehm.) Ravenna]. Chromosome sizes and total DNA content vary considerably among the species, although the relative chromosome sizes and bimodality are maintained within the karyotypes of each species. Our studies on Cypella species from southern Brazil (C. fucata Ravenna, C. hauthalii R.C. Foster, $C$. herbertii (Lindl.) Herb. and C. osteniana Beauverd ssp. aurantiaca Roitman \& A. Castillo) have confirmed $x=7$ for these species.

Like Cypella and Calydorea species, Herbertia species have a basic number of $x=7$. Four ploidy levels $(2 x, 4 x$, $6 x$, and $8 x$ ) have been found in South American Herbertia species (Winge, 1959; Goldblatt and Takei, 1997; Roitman and Castillo, 2004; Moreno et al., 2009). Intraspecific polyploid series were also reported for Herbertia lahue (Molina) Goldblatt $(2 n=14,28,42$, or 56) and H. pulchella Sweet $(2 n=14,28$, or 42) (Kenton and Heywood, 1984; Goldblatt and Takei, 1997; Moreno et al., 2009). Moreno et al. (2009) carried out a detailed karyotype analysis of three Herbertia species from Argentina and confirmed the four ploidy levels already described for the genus. H. darwinii, whose chromosome number is reported for the first time in this paper is diploid $(2 n=14)$, whereas $H$. quareimana is a tetraploid confirming previous data (Kenton and Heywood, 1984; Goldblatt and Takei, 1997). Two cytotypes were observed for $H$. lahue ssp. amoena, one hexaploid with $2 n=42$ and one octoploid with $2 n=56$. The mean chromosome length ranges between 2.6 and $2.9 \mu \mathrm{m}$. According to the authors, the polyploid cytotype has a symmetric karyotype, while the diploid $H$. darwinii has a bimodal one. Chromosome banding and fluorescence in situ hybridiza- tion were also performed. One ongoing study of our group concerning six Herbertia species endemic from southern Brazil shows that all of them have $x=7$ and four ploidy levels can be found, confirming previous studies.

Sisyrinchium is the Iridaceae genus with the largest amount cytological data, although data for the South American Sisyrinchium species are still scarce (Goldblatt, 1982; Kenton et al., 1986; Goldblatt and Takei, 1997). Although $x=5,8,9$, and 17 have been found, $x=8$ and $x=9$ are the more frequent ones, with 9 being considered the ancestral chromosome number (Chauveau et al., 2011). The remaining secondary basic numbers apparently have evolved through decreasing disploidy and/or ancestral hybridization between $x=8$ and $x=9$ species, followed by polyploidization (Rudall et al., 1986; Goldblatt and Takei, 1997). According to Kenton and Heywood (1984), the most frequent $x$ value for Sisyrinchium from the Southern Hemisphere is 9, whereas for those in the Northern Hemisphere $x=8$ is more common.

Our research group has obtained chromosome numbers for 14 Sisyrinchium species, 10 of them for the first time; all but one have an $x=9$ (Corrêa, unpublished data), the exception is $S$. micranthum with $x=8$ (Tacuatiá et al. 2012b), consistent with literature data (Goldblatt and Takei, 1997).

Intraspecific cytotypes were observed in $S$. micranthum, and although three ploidy levels were found, diploidy was most common. Polyploidy seems to be an important factor in Sisyrinchium evolution, as more than $70 \%$ of the studied species are polyploids (Goldblatt and Takei, 1997). Whereas the Southern Hemisphere has more diploid than polyploid Sisyrinchium species, higher ploidy levels, such as octo- and dodecaploidy, have been found in Sisyrinchium species of the Northern Hemisphere. Cytological data of Goldblatt (1982), Kenton and Heywood (1984), Kenton et al. (1986) and Rudall et al. (1986) suggested that ploidy level increases with latitude, also indicating a higher level of heterozygosity for the colonization of peripheral habitats. An allopolyploid origin of many cytotypes was suggested by Kenton et al. (1986); however, consistent data are not available. Sisyrinchium chromosomes are very small, especially in $x=8$ species, making it difficult to perform karyotypical analyses (Kenton et al., 1986). Karyotype symmetry tends to correlate with large genomes in Sisyrinchium species (Kenton and Heywood, 1984; Kenton et al., 1986).

Goldblatt et al. (1984) suggested that karyotype evolution in Iridaceae has been accompanied by increases and decreases in genome size. The DNA content of several Iridaceae species has been determined, primarily for the genus Sisyrinchium, (Goldblatt et al., 1984; Kenton et al., 1986; Kenton et al., 1990). The haploid genomes ( $C$-value) of Sisyrinchium species range from 0.25 to $3.26 \mathrm{pg}$ DNA, with the largest variation in genome size found in $x=9$ species of the Echthronema section. Kenton et al. (1986) re- 
ported that diploid species in the Southern Hemisphere exhibit a positive and significant relationship between genome size and latitude. Variation in genome size seems to be also related to life cycle, with annual plants tending to have smaller genomes than perennials. DNA measurements in Sisyrinchium species from southern Brazil show little variation in monoploid genome size $(C x)$, although hexaploids have less DNA (Souza-Chies and Kaltchuk dos Santos, unpublished data). Such reduction may be a result of the "downsizing" phenomenon. We have observed that genome size is considerably larger in Calydorea, Cypella, and Herbertia than in Sisyrinchium, as expected considering the respective chromosome sizes. In Cypella species, which have larger chromosomes than Sisyrinchium species, genome size ranges from 2.03 to $2.39 \mathrm{pg}$ (Kenton et al., 1990). Species of the genera with $2 n=14$ have $C$ values of approximately $4 \mathrm{pg}$. Herbertia polyploids have proportionally higher DNA contents, but all have similar $C x$ values.

\section{Evolution and General Features}

\section{Calydorea}

Calydorea comprises approximately 16 species native to South America (Goldblatt and Manning, 2008; Goldblatt et al., 2008). Calydorea species have equal or subequal tepals that range in color from white to dark purple. In southern Brazil, the genus presents an interesting distribution, with typical species belonging to different biomes: C. basaltica Ravenna, C. crocoides (Figure 1A), and $C$. longipes Ravenna occur mainly in the Atlantic Forest biome, whereas C. alba (Figura 1B) and its allies are endemic of the Pampa biome (Ravenna, 1965, 2005a,b; Roitman and Castillo, 2005).

The taxonomy of Calydorea is bewildering because of the placement of many different genera that expand its circumscription. Based on a cladistic analysis using morphological data, Goldblatt and Henrich (1991) concluded that Cardiostigma Baker, Salpingostylis Small, Catila Ravenna, and Itysa Ravenna are synonyms of Calydorea. Goldblatt and Manning (2008) proposed that Calydorea includes provisionally Catila, Itysa, Lethia Ravenna, and Tamia Ravenna. The most recent study of Iridaceae phylogeny included only two Calydorea species, which did not group together in the phylogenetic trees (Goldblatt et al., 2008). Considering the number of species involved in the analysis, phylogenetic relationships still need to be clarified.

De Tullio et al. (2008), through morphological and cytological approaches, evaluated the validity of Tamia pallens (Griseb.) Ravenna and C. undulata and proposed that Tamia pallens should be regarded as a synonym of $C$. pallens because the floral divergences are insufficient for segregation to the genus Tamia. This conclusion was corroborated by their very similar karyotypes. On the other hand, the authors argued for the validity of $C$. undulata.
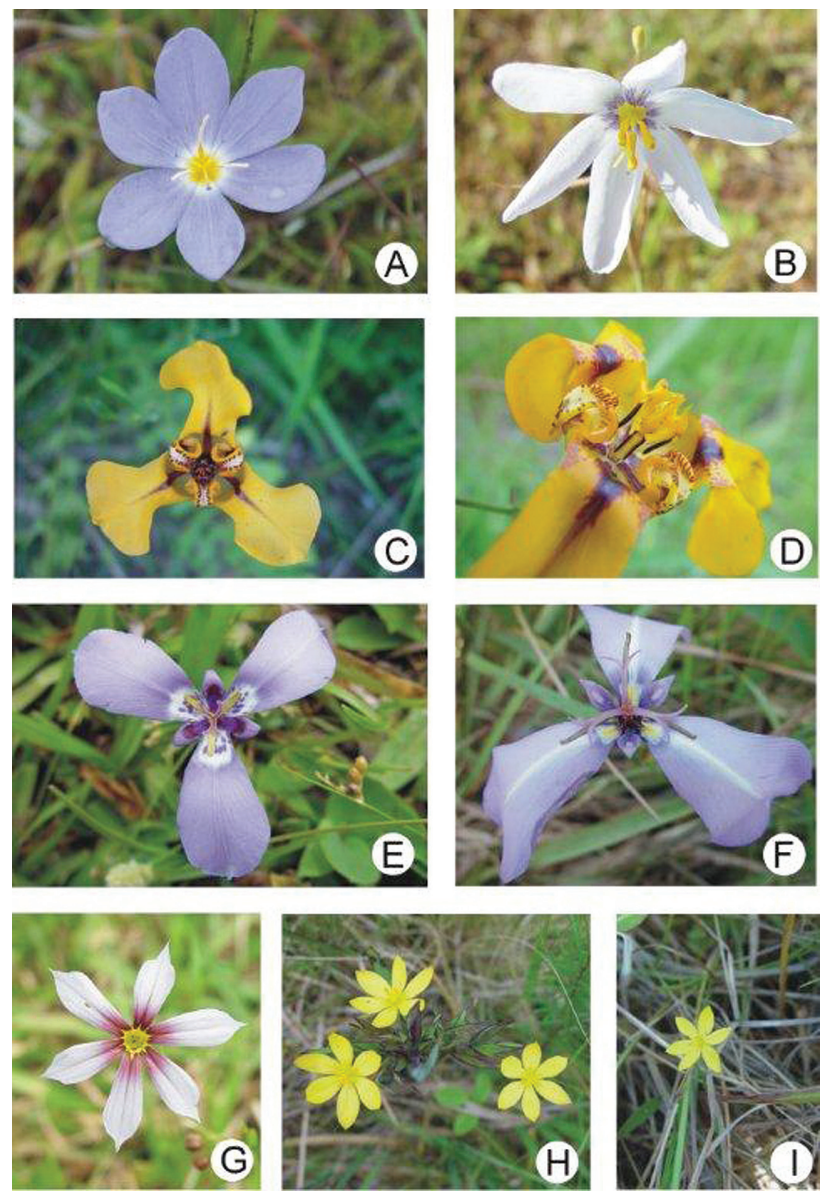

Figure 1 - Flowers of species cited in this study: (A) Calydorea crocoides Ravenna; (B) Calydorea alba Roitman \& A. Castillo; (C) Cypella herbertii (Lindl.) Herb.; (D) Cypella fucata Ravenna; (E) Herbertia lahue (Molina) Goldblatt; (F) Herbertia pulchella Sweet; (G) Sisyrinchium micranthum Cav.; (H) Sisyrinchium palmifolium L.; (I) Sisyrinchium vaginatum Spreng. Photographs: L. Eggers.

This panoramic survey clearly shows that a detailed phylogenetic study of Calydorea is necessary to clarify these relationships and our team is now working toward this goal. Data about the genetic divergence or evolutionary aspects of Calydorea species are lacking, even though the plants are representative of the south Brazilian vegetation. We are now focusing on the genetic variability of $C$. crocoides, an endemic species from the Campos de Cima da Serra region of Rio Grande do Sul, based on inter-sequence simple repeat (ISSR) markers. Preliminary data suggest that the analyzed populations are structured $\left(\phi_{\mathrm{ST}}=0.240\right)$, indicating little gene flow among populations. These data are still preliminary and few populations were analyzed until this moment. However, it is interesting to mention that the species $C$. crocoides presents a very limited geographical distribution and therefore the populations are geographically close. Thus, it seems that other factors besides geographical separation between populations are influencing the geographical structure of the populations 
analyzed, such as breeding system and dispersion of pollen and seeds.

\section{Cypella}

Most Cypella species are native to South America (Goldblatt et al., 2008), with some species occurring in Central America and Mexico. Their flowers are characterized by two different whorls of tepals and thickened style branches with terminal crests that provide complex flower morphology for preservation and analysis. The flowers are usually orange or yellow, but creamy, white and blue ones also occur. Most of the Cypella species in southern Brazil were described by Ravenna (1981), but a comprehensive review of the genus is needed. The most common known species of Cypella in southern Brazil are C. herbertii and $C$. fucata (Figure 1C, 1D, respectively).

Cypella provisionally includes the genera Kelissa Ravenna, Onira Ravenna, and Phalocallis Herb. (Goldblatt and Manning, 2008). The genus consists of approximately 30 species (Goldblatt et al., 2008), but this number varies according to the accepted circumscription. Taxonomy of Cypella remains controversial, and recent phylogenetic research has indicated that it is paraphyletic (Celis et al., 2008; Goldblatt et al., 2008). In phylogenetic studies of Iridaceae (Souza-Chies et al., 1997; Reeves et al., 2001; Rodriguez and Sytsma, 2006; Celis et al., 2008; Goldblatt et al., 2008), Cypella is usually underrepresented. In the most recent and most complete phylogenetic overview of Iridaceae, Goldblatt et al. (2008) analyzed three species of Cypella and the genus appeared as polyphyletic, including Cipura Aubl., Nemastylis Nutt., Herbertia, Onira, and Calydorea. The relationships among Cypella, Phalocallis, and the monotypic genera Kelissa and Onira remain to be determined using molecular data (Goldblatt and Manning, 2008).

The morphologically related Cypella species $C$. fucata, $C$. herbertii, and C. osteniana remain unanalyzed in the published phylogenies. Cypella fucata and C. herbertii have been the focus of some evolutionary studies, including studies of the breeding systems of $C$. herbertii (Devoto and Medan, 2003) and of the molecular diversity among populations of C. fucata (De Marco et al., 2009). Like other Iridaceae, some Cypella species, such as $C$. herbertii, are known to produce lipidic oils in elaiophores as a reward for their highly specific pollinator bees, a feature that is very important in the evolution of the genus (Goldblatt and Manning, 2008).

After testing the effects of grazing disturbance on $C$. herbertii reproduction, Devoto and Medan (2003) concluded that grazing disturbance might greatly reduce the quantity and quality of pollinators for one population of the species. In three years of observations, visits by the specialist oil-bee pollinator Chalepogenus Holmberg (1903) were recorded only for flowers inside cattle-free exclosures and never for those outside the exclosures. Although little im- pact on the mating system was noted, this finding raises the possibility of a risk of extinction of this species highly dependent of specialized pollinators (Devoto and Medan, 2003).

Cypella fucata is the only Cypella species for which a population analysis has been done (De Marco et al., 2009). It is a wild plant with populations that are often formed by few individuals only. Two populations of $C$. fucata separated by $22 \mathrm{~km}$ were studied using dominant ISSR markers and the data indicated gene flow between the populations $\left(\phi_{\mathrm{ST}}=0.0851\right.$ with an intermediate structure $)$ and high identity between the two collection sites (98\%). These results suggest that $C$. fucata cross-pollinates and that vegetative propagation does not play an important role in the maintenance of the populations (De Marco et al., 2009).

\section{Herbertia}

Herbertia comprises approximately seven species distributed in temperate regions of South America and the southern United States (Goldblatt and Manning, 2008). Herbertia flowers are predominantly violet, with tepals of different sizes, and anthers appressed to style branches. The two most common species of the genus in southern Brazil are H. lahue (Figure 1E) and H. pulchella (Figure 1F). These two plants can be readily distinguished by the larger size and the presence of a conspicuous white middle streak on the outer tepals of $H$. pulchella.

Reconstruction of Iridaceae phylogeny using DNA sequences has demonstrated a close relationship between Cypella and Herbertia, which together form a clade with Calydorea and Cipura (Reeves et al., 2001; Goldblatt and Manning, 2008, Goldblatt et al., 2008). To date, the major taxonomic problem concerning Herbertia is the delimitation of species which exhibit both a great affinity in vegetative features and a high variability in some aspects of floral morphology. Moreover, the flowers are ephemeral and poorly preserved as herbarium material, making the identification of herbarium specimens difficult (Rodriguez and Sytsma, 2006; Goldblatt et al., 2008). Thus, morphotype differentiation and characterization of species based exclusively on morphological characters are not recommended and a combination of data sets on morphological and molecular traits is advised for a reasonable analysis.

There are no reported studies of Herbertia using molecular markers for the comprehension of intra- and interspecific diversity. Our research group is currently conducting a study based on dominant markers, such as ISSR-PCR and preliminary results already permit some differentiation between morphotypes of H. lahue, consistent with other studies on Crocus L. and Iris L. (Caiola et al., 2004; Sik et al., 2008; Saad and Mahy, 2009). A preliminary analysis of $H$. lahue has indicated that the largest source of variation occurs among populations $\left(\phi_{\mathrm{ST}}=0.82\right.$, $\mathrm{p}<0.001$ ). These differences may be related to self-fertilization, which was indicated already in earlier results on 
the H. lahue reproductive system. Additionally, variation in floral morphology verified among populations is possibly related to differentiation associated with selfing. Similar results were found in the Iris section Oncocyclus (Saad and Mahy, 2009) and in Iris bismarckiana Dammann \& Sprenger (Sadder, 2007), both of which were analyzed with Random Amplified Polymorphic DNA (RAPD) markers.

In three populations of $H$. quareimana, our initial ISSR study points to a situation different from that in $H$. lahue, as a similar degree of differentiation was observed between $\left(\phi_{\mathrm{ST}}=0.475\right)$ and within $\left(\phi_{\mathrm{IS}}=0.52\right) H$. quareimana populations $(\mathrm{p}<0.001)$. So far, these results differ from those obtained by RAPD analyses of Iris aphylla $\mathrm{L}$. and Crocus sativus L., in which the greatest source of diversity was observed within populations (Wroblewska et al., 2003; Beiki et al., 2010). Factors like number of markers used in the analysis, the distribution across the genome and the number of sampled individuals can affect distance estimates. The estimates obtained so far are preliminary and more loci need to be added to the analysis. Nevertheless, some inference is already possible. Initial experiments have indicated that $H$. quareimana is mainly cross-pollinated, while $H$. lahue produces fruit also by self-fertilization. Observations of floral visitors in $H$. quareimana and $H$. lahue sympatric populations have shown that the main visitors are honey bees, Apis mellifera L., which prefer flowers of $H$. quareimana and visite $H$. lahue only secondarily. The geographical distance between populations is also considered an influential factor in estimates of genetic differentiation, highlighting the need for sampling more populations, especially in the case of $H$. lahue, which has a wider distribution, occurring in virtually all regions of the State of Rio Grande do Sul, where it is also in sympatry with other Herbertia species such as $H$. darwinii and $H$. pulchella. In the case of $H$. quareimana, its geographical distribution is concentrated in the western region of the state and some populations occur in sympatry with $H$. lahue. In the case of $H$. quareimana, none of its populations was observed to occur in sympatry with other Herbertia species.

\section{Sisyrinchium}

Sisyrinchium extends throughout South, Central and North America, with one species in Greenland. The species are associated primarily with two major centers of distribution, Mexico and South America, with a conservative estimate of approximately 140 species in the Americas (Goldblatt and Manning 2008). Sisyrinchium has been suggested to be of South American origin (Goldblatt et al., 2008; Chauveau et al., 2011). For the Southern Hemisphere, its biogeographical pattern indicates expansions from Central America and the northern Andes to the subAndean ranges between Chile and Argentina and to the area of the Paraná river basin (Chauveau et al., 2011).
Sisyrinchium has radially symmetric yellow, pale, dark blue or purple flowers. Its species can be distinguished by leaf traits (e.g., cylindrical $v s$. linear, presence of caulinate leaves) and flower characters, particularly aspects of androecium organization. Filaments can be partly connected or completely fused in a staminal column that may bear trichomes of different types, including elaiophores (Goldblatt and Manning, 2008).

Sisyrinchium plants are usually found in open areas, grasslands, rocky formations, or wet environments and are sometimes found in ruderal habitats. Some species, such as S. micranthum (Figure 1G) are widespread in southern Brazil, whereas others, such as S. rambonis R.C. Foster, occur only in environments with specific ranges of humidity and altitude (Foster, 1950; personal observation).

Phylogenetic evidence from Iridoideae based on five plastid DNA regions strongly suggests that Sisyrinchium is closely related to the four other genera of tribe Sisyrinchieae (Libertia, Orthrosanthus, Olsynium, and Solenomelus) (Goldblatt et al., 2008). The infrageneric taxonomy of Sisyrinchium has been studied over many years, based primarily on morphological traits and, more recently, on molecular characteristics. However, the systematics of the genus remain poorly resolved because of the weedy, self-fertile nature of its species and the high morphological similarity between closely related taxa, which is attributable to a recent adaptive radiation process resulting in the emergence of species complexes (Goldblatt, 1982; Chauveau et al., 2011).

A recent phylogenetic study of Sisyrinchium combining eight molecular markers of the plastidial, mitochondrial, and nuclear genomes (Chauveau et al., 2011) confirmed its monophyly and revealed nine major clades weakly connected to the unfinished subdivision established by Ravenna, with some exceptions. Chauveau et al. (2011) suggested that changes in the classification of the sections are needed, especially in the clades including species from southern Brazil. The section Hydastylus appears to be polyphyletic, and a new taxonomic treatment of the species allocated to this section is required. Tree topology showed a clade formed by the $S$. palmifolium complex (section Hydastylus) and the $S$. vaginatum complex (section Viperella), which is a well-supported monophyletic group. A similar result was observed for the section Sisyrinchium, whose circumscription needs to be reviewed because species of the section were present in at least three wellsupported clades, the main one including specimens of $S$. micranthum, the related $S$. laxum Otto ex Sims and $S$. rosulatum E.P. Bicknell. Species belonging to section Lenitium and to section Scirpeocharis are grouped in a single clade in the phylogeny, suggesting that these sections correspond to a unique natural group. Sisyrinchium sellowianum, placed by Ravenna in the section Lenitium, is related to species belonging to section Scirpeocharis, including S. luzula, both found in southern Brazil. 
We have examined the genetic structure within and among populations belonging to four complexes of Sisyrinchium species (S. micranthum, S. palmifolium - Figure $1 \mathrm{H}$, S. sellowianum, and $S$. vaginatum - Figure 1I) based on ISSR markers (Table 1). Genetic differentiation among populations of $S$. micranthum, $S$. palmifolium, $S$. sellowianum, and $S$. vaginatum was considerable $\left(\phi_{\mathrm{ST}}=0.3528,0.4700,0.4370\right.$, and 0.4537 , respectively $)$ and a higher intrapopulation genetic variability was observed $\left(\phi_{\mathrm{IS}}=0.6472,0.5300,0.5630\right.$ and 0.5463 , respectively), the genetic differentiation among populations indicates a high structure. The Nei (h) genetic identity index (Nei, 1973) and the Shannon (I) index of phenotypic diversity (Shannon and Weaver, 1949) were tested for these four groups of species with the following results: S. micranthum $(\mathrm{h}=0.1819, \mathrm{I}=0.2750)$, S. palmifolium $(\mathrm{h}=0.1563$, $\mathrm{I}=0.2626), S$. sellowianum $(\mathrm{h}=0.2945, \mathrm{I}=0.4535)$ and $S$. vaginatum $(\mathrm{h}=0.2445, \mathrm{I}=0.3839)$. The lowest values of diversity were observed for $S$. micranthum (Tacuatiá et al., 2012a) and S. palmifolium, whereas S. sellowianum showed the highest values, which is consistent with the identity of the Nei index calculated for the analyzed complexes.

The genetic variability and genetic differentiation observed for the populations of these complexes may indicate reduced gene flow, probably due to geographical distance and fragmentation of populations, resulting in high genetic structure. High levels of genetic differentiation might be explained by several factors, such as the species breeding system, genetic drift, demographic fluctuations, or the genetic and geographic isolation of populations (Hogbin and Peakall, 1999).

At the present time, the analysis indicated no significant correlation between geographic and genetic distances for the four complexes of species (Table 1). The lack of correlation may be due to the fact that we analyzed complexes of species, encompassing more than one taxonomic entity (or species) and with distinct genomes. Furthermore, several evolutionary processes can affect the lack of correlation, for example, a founder effect and habitat fragmenta-

Table 1 - Indices of genetic variability for Sisyrinchium species.

\begin{tabular}{lccccc}
\hline \multirow{2}{*}{ Species } & \multicolumn{2}{c}{$\Phi$} & $\mathrm{h}$ & $\mathrm{I}$ & $\mathrm{r}$ \\
\cline { 2 - 4 } & $\mathrm{ST}$ & $\mathrm{IS}$ & & & \\
\hline S. micranthum & $0.3528^{*}$ & $0.6472^{*}$ & 0.1819 & 0.2750 & 0.266 \\
S. palmifolium & $0.4700^{*}$ & $0.5300^{*}$ & 0.1563 & 0.2626 & 0.16 \\
S. sellowianum & $0.4370^{*}$ & $0.5630^{*}$ & 0.2945 & 0.4535 & 0.101 \\
S. vaginatum & $0.4537^{*}$ & $0.5463^{*}$ & 0.2445 & 0.3839 & 0.240 \\
\hline
\end{tabular}

$\Phi_{\mathrm{ST}}=$ interpopulation genetic differentiation coefficient; $\Phi_{\mathrm{IS}}=$ intrapopulation genetic differentiation coefficient; $h=$ Nei's genetic identity (Nei, 1973); I = Shannon index of phenotypic diversity (Shannon and Weaver, 1949); $r=$ Mantel test.

$* \mathrm{p}>0.01$. tion. The sites of collection of these plants are areas of agricultural use and grasslands, factors which normally reduce population size and restrict the possibility of gene flow between populations.

According to Hamrick and Godt (1989), reproductive biology is the most important determinative factor in the genetic structure of plant populations. They showed that outcrossing plant species tend to have $10 \%$ to $20 \%$ of genetic variation among populations, whereas selfing species have, on average, $50 \%$ of variation among populations. Thus, our data suggest that the analyzed species preferentially reproduce by selfing. Genetic diversity within populations is considered to be of high importance for the adaptation to fluctuating environments and, as a consequence, for the long-term survival of a species.

\section{Conclusions}

The present work reviews what is known about the genetic diversity and evolution of species belonging to the genera Calydorea, Cypella, Herbertia, and Sisyrinchium from southern Brazil. Diversity indexes obtained illustrate the genetic differentiation of populations that occur in grasslands of southern Brazil. With the exception of $C$. fucata, these populations are generally well structured. The available cytogenetic evidence indicates that polyploidy events have been important in Iridaceae speciation processes. Phylogenetic studies have clearly demonstrated the need for a review of the taxonomical circumscription of these genera, an exception being the genus Sisyrinchium. Phylogenetic results for Sisyrinchium allow to reconstruct the evolution of glandular trichomes, which occurred independently three times in this genus. Evolutionary studies of Sisyrinchium suggest that oil-producing trichomes may have played a key role in its diversification. The other genera should also be tested for glandular trichomes that attract specialized pollinators.

\section{References}

Alves LI, Lima SAA and Felix LP (2011) Chromosome characterization and variability in some Iridaceae from Northeastern Brazil. Genet Mol Biol 34:259-267.

Beiki AH, Keifi F and Mozafari J (2010) Genetic differentiation of Crocus species by Random Amplified Polymorphic DNA. Genet Eng Biotechnol J 18:1-10.

Caiola MG, Caputo P and Zanier R (2004) RAPD analysis in Crocus sativus L. accessions and related Crocus species. Biol Plant 48:375-380.

Celis M, Rodriguez A, Goldblatt P, Rudall P and Sauquet H (2008) Phylogenetic relationships in Tigrideae (Iridaceae) based on plastid and nuclear ITS DNA sequences. In: The Fourth International Conference: The Comparative Biology of the Monocotyledons - Abstracts, p. 15, Monocots IV.

Chauveau O, Eggers L, Raquin C, Silvério A, Brown S, Couloux A, Cruaud C, Kaltchuk-Santos E, Yockteng R, Souza-Chies TT, et al. (2011) Evolution of oil-producing trichomes in Sisyrinchium (Iridaceae): Insights from the first comprehen- 
sive phylogenetic analysis of the genus. Ann Bot 107:12871312.

Chukr NS and Capellari Jr L (2003) Iridaceae. In: Wanderley MGL, Shepherd GJ, Giulietti AM and Melhem TS (eds) Flora Fanerogâmica do Estado de São Paulo. RiMa, São Paulo, pp 127-147.

De Marco EG, Tacuatiá LO, Eggers L, Kaltchuk-Santos E and Souza-Chies TT (2009) Genetic variability within Cypella fucata Ravenna in Southern Brazil. In: Mahoney CL and Springer DA (eds) Genetic Diversity. Nova Science Publishers, New York, pp 179-194.

De Tullio L, Roitman G and Bernardello G (2008) Tamia (Iridaceae), a synonym of Calydorea: Cytological and morphological evidence. Syst Bot 33:509-513.

Devoto M and Medan D (2003) Effects of grazing disturbance on the reproduction of a perennial herb, Cypella herbertii (Lindl.) Herb. (Iridaceae). Plant Syst Evol 243:165-173.

Eggers L, Chukr N, Lovo J and Gil A (2010) Iridaceae. In: Forzza RC, Baumgratz JFA, Bicudo CEM, Carvalho Jr. AA, Costa A, Costa DP, Hopkins M, Leitman PM, Lohmann LG, Maia LC, et al. Lista de Espécies da Flora do Brasil. Jardim Botânico do Rio de Janeiro, Rio de Janeiro, pp 1122-1128.

Foster RC (1950) Studies in the Iridaceae VI. Contr Gray Herb 171:22-28.

Goldblatt P (1982) Chromosome cytology in relation to suprageneric systematics of Neotropical Iridaceae. Syst Bot 7:186198.

Goldblatt P (1990) Phylogeny and classification of the Iridaceae. Ann Missouri Bot Gard 77:607-627.

Goldblatt P and Henrich E (1991) Calydorea Herbert (IridaceaeTigrideae): Notes on this New World genus and reduction to synonymy of Salpingostylis, Cardiostigma, Itysa and Catila. Ann Missouri Bot Gard 78:504-511.

Goldblatt P and Manning JC (2008) The Iris Family: Natural History and Evolution. Timber Press, Oregon, 290 pp.

Goldblatt P and Takei M (1997) Chromosome cytology of Iridaceae, patterns of variation, determination of ancestral base numbers, and modes of karyotype change. Ann Missouri Bot Gard 84:285-304.

Goldblatt P, Walbot W and Zimmer EA (1984) Estimation of genome size (C-value) in Iridaceae by cytophotometry. Ann MO Bot Gard 71:176-180.

Goldblatt P, Rodriguez A, Powell MP, Davies TJ, Manning JC, Van der Bank M and Savolainen V (2008) Iridaceae 'Out of Australasia'? Phylogeny, biogeography, and divergence time based on plastid DNA sequences. Syst Bot 33:495-508.

Hamrick JL and Godt MJ (1989) Allozyme diversity in plant species. In: Brown ADH, Clegg MT, Kahler AL and Weir BS (eds) Plant Population Genetics, Breeding and Genetic Resourses. Sinauer Associates, Sunderland, pp 43-63.

Hogbin PM and Peakall R (1999) Evaluation of the contribution of genetic research to the management of the endangered plant Zieria prostrate. Conserv Biol 13:514-522.

Johnston IM (1938) The species of Sisyrinchium in Uruguay, Paraguay and Brazil. J Arnold Arbor 19:376-401.

Kenton A and Heywood CA (1984) Cytological studies in South American Iridaceae. Plant Syst Evol 146:87-104.

Kenton AY, Rudall PJ and Johnson AR (1986) Genome size variation in Sisyrinchium L. (Iridaceae) and its relationship to phenotype and habitat. Bot Gaz 147:342-354.
Kenton A, Dickie JB, Langton DH and Bennett MD (1990) Nuclear DNA amount and karyotype symmetry in Cypella and Hesperoxiphion (Tigridieae, Iridaceae). Evol Trends Plants 4:59-69.

Michener CD (2007) The Bees of the World. Johns Hopkins University Press, Baltimore, $953 \mathrm{pp}$.

Moreno N, Las Peñas ML, Bernardello G and Roitman G (2009) Cytogenetic studies in Herbertia Sw. (Iridaceae). Caryologia 62:37-42.

Nei M (1973) Analysis of gene diversity in subdivided populations. Proceedings of the National Academy of Sciences 70:3321-3323.

Ravenna P (1965) Notas sobre Iridaceae II. Bol Soc Argent Bot 10:311-322.

Ravenna P (1981) Eight new species and two new subspecies of Cypella (Iridaceae). Wrightia 7:13-22.

Ravenna P (2005a) New species of South American bulbous Iridaceae: Calydorea basaltica. Onira 10:40.

Ravenna P (2005b) New species of South American bulbous Iridaceae: Calydorea longipes. Onira 10:41.

Reeves G, Chase MW, Goldblatt P, Rudall P, Fay MF, Cox AV, Lejeune B and Souza-Chies T (2001) Molecular systematics of Iridaceae: Evidence from four plastid DNA regions. Am J Bot 88:2074-2087.

Renner SS and Schaefer H (2010) The evolution and loss of oil-offering flowers: New insights from dated phylogenies for angiosperms and bees. Philos Trans R Soc Lond B Biol Sci 365:423-435.

Rodriguez A and Sytsma KJ (2006) Phylogenetics of the "tiger-flower" group (Tigridieae, Iridaceae): Molecular and morphological evidence. Aliso 22:412-424.

Roitman G and Castillo A (2004) A new species, Herbertia crosae (Iridaceae), from Uruguay. Brittonia 56:361-364.

Roitman G and Castillo A (2005) Calydorea alba (Iridaceae, Tigridieae), a new species from Uruguay. Bol Soc Argent Bot 40:311-312.

Rudall P, Kenton AY and Lawrence TJ (1986) An anatomical and chromosomal investigation of Sisyrinchium and allied genera. Bot Gaz 147:466-477.

Sadder MT (2007) Molecular polymorphism of newly reported endemic Iris bismarckiana (Iris sect. Oncocyclus) in Jordan. Jordan J Agric Sci 3:262-270.

Saad L and Mahy G (2009) Molecular and morphological variation of rare endemic oncocyclus irises (Iridaceae) of Lebanon. Bot J Linn Soc 159:123-135.

Shannon CE and Weaver W (1949) The Mathematical Theory of Communication. University of Illinois Press, Urbana, $144 \mathrm{pp}$.

Sik L, Candan F, Soya S, Karamenderes C, Kesercioglu T and Tanyolac B (2008) Genetic variation among Crocus L. species from Western Turkey as revealed by RAPD and ISSR markers. Flora 2:73-75.

Souza-Chies TT, Bittar G, Nadot S, Carter L, Besin E and Lejeune B (1997) Phylogenetic analysis of Iridaceae with parsimony and distance methods using the plastid gene rps4. Plant Syst Evol 204:109-123.

Tacuatiá LO, Eggers L, Kaltchuk-Santos E and Souza-Chies TT (2012a) Population genetic structure of Sisyrinchium micranthum Cav. (Iridaceae) in Itapuã State Park, Southern Brazil. Genet Mol Biol 35:99-105. 
Tacuatiá LO, Souza-Chies TT, Eggers L, Siljak-Yakovlev S and Santos EK (2012b) Cytogenetic and molecular characterization of morphologically variable Sisyrinchium micranthum (Iridaceae) in southern Brazil. Bot J Linn Soc 169:350-364.

Winge H (1959) Studies on cytotaxonomy and polymorphism of the genus Alophia (Iridaceae). Rev Bras Biol 19:195-201.

Wróblewska A, Brzosko E, Czarnecka B and Nowosielski J (2003) High levels of genetic diversity in populations of Iris aphylla L. (Iridaceae), an endangered species in Poland. Bot J Linn Soc 142:65-72.

License information: This is an open-access article distributed under the terms of the Creative Commons Attribution License, which permits unrestricted use, distribution, and reproduction in any medium, provided the original work is properly cited. 